\title{
Physicochemical properties of Butter cheese from Marajó manufactured with buffalo milk and cow milk
}

\author{
Marilda Garcia Simões ${ }^{1}$, Joseane Gonçalves Rabelo ${ }^{1}$, Rosane Esmeralda Portal ${ }^{1}$, \\ Alessandra Ferraiolo Nogueira Domingues ${ }^{2}$, Eduardo Basílio Oliveira ${ }^{3}$, \\ Célia Lúcia de Luces Fortes Ferreira ${ }^{3}$ \\ ${ }^{I}$ Department of Food and Technology, College of Food Technology, State University of Pará, Brazil \\ ${ }^{2}$ Embrapa, Agribusiness, Brazil \\ ${ }^{3}$ Department of Food and Technology, College Food Engineering, Federal University of Viçosa, Brazil
}

\begin{abstract}
This study aimed to evaluate the physicochemical characteristics, texture and color parameters of the artisanal Butter cheese from Marajó, manufactured with partial substitution of buffalo milk for cow milk. Four formulations were elaborated: $B_{100}$ (100\% buffalo milk); $B_{80}\left(80 \%\right.$ buffalo milk $+20 \%$ cow milk); $B_{70}$ (70\% buffalo milk $+30 \%$ cow milk) and $B_{60}(60 \%$ buffalo milk $+40 \%$ cow milk). Three replicates were performed. The partial substitution of $20 \%, 30 \%$ and $40 \%$ of buffalo milk caused the reduction of fat in $16.2 \%$, $21.6 \%$ and $25.4 \%$, and protein in $5.2 \%, 5.7 \%$, and $6 \%$, respectively, with decrease of elasticity, cohesiveness, gumminess and chewiness, but had no influence on the hardness. Moisture had significant and strongly negative correlation with elasticity, cohesiveness, gumminess and chewiness. Fat and protein had significant and strongly positive correlations with elasticity, cohesiveness, gumminess and chewiness. Significant differences were found for color variables $L^{*}, a^{*}, b^{*}$ and $h^{o}$. The increase in cow milk concentration increased the yellowgreenish tonality, with an emphasis in yellow tones.
\end{abstract}

Keywords: color, Marajó "Butter cheese", physicochemical composition, texture TPA.

\section{Introduction}

The artisanal Butter cheese, are cheeses produced for almost two centuries on Marajó Island, the largest fluvial-marine island in the world, located in the northern region of Brazil, is the result of a centennial tradition passed down through the generations as a way to use the milk production of buffalos bred on small rural farms, and a source of income and work for the considerable number of producers on the island.

Before the introduction of buffalo in the Island, at the end of XIX century, the production of this cheese was exclusively made with bovine milk. However, with the expressive growth of the buffalo herd, due to the presence of natural pastures and floodplains, the production of buffalo milk increased, and it started to be mixed with bovine milk in cheese production [1]. Thus, since this time, the artisanal cheeses of Marajó started to be produced almost exclusively with buffalo milk.

Today, this cheese is produced from the spontaneous fermentation of raw buffalo milk and/or buffalo added with bovine milk at a maximum proportion of $40 \%$ [2], being obtained by fusion and intended for immediate consumption. However, the mixture of those milks may bring alterations in physicochemical characteristics, texture and color parameters, caused by bovine milk composition that has a lower amount of fat, lactose, protein, ashes, $\mathrm{Ca}$ and $\mathrm{A}$ and $\mathrm{C}$ vitamins, and higher concentration of $\beta$-carotene, absent in buffalo milk

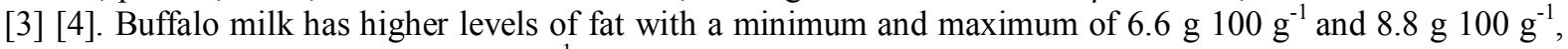

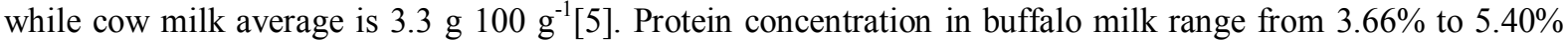
and in cow milk average is $3.2 \%$ [5].

Cheese is a visco-elastic material formed by a net of casein where dispersed globules of fat and water determine its texture [6]. The texture is identified by consumers as one of the most important attributes of cheese quality [7] and the most important sensorial characteristics, because it allows the consumer to identify specific varieties and their qualities, even before evaluating the flavor [8]. The texture characteristic of cheese is influenced by several factors, one of the most relevant being the raw-material composition [8] and changes on these parameters are caused by concentrations of protein, salt, water, $\mathrm{pH}$ and fat, in this order [9]. In addition, color parameters acting as a differential in characterization of different types of cheese [10].

The purpose of this work was to evaluate physicochemical characteristics, texture and color parameters of artisanal Marajó Butter cheese produced with different concentrations of buffalo milk and cow milk. 


\subsection{Formulations of Butter Cheese}

\section{Material and Methods}

In this study, four formulations of the Butter Cheese were produced with buffalo and cow milk; all were processed in a cheese factory located in the municipality of Cachoeira do Arari, on the Marajó Island. The milk (buffalo and cow) came from the same rural property. The four formulations are designed by: $\mathrm{B}_{100}(100 \%$ buffalo milk); $\mathrm{B}_{80}(80 \%$ buffalo milk $+20 \%$ cow milk $) ; \mathrm{B}_{70}(70 \%$ buffalo milk $+30 \%$ cow milk $)$ and $\mathrm{B}_{60}(60$ $\%$ buffalo milk $+40 \%$ cow milk). Three replicates were performed. One cheese from each formulation was selected for analysis. The cheeses were produced according to process used by Marajó's producers, as shown in the workflow diagram depicted in Fig. 1.

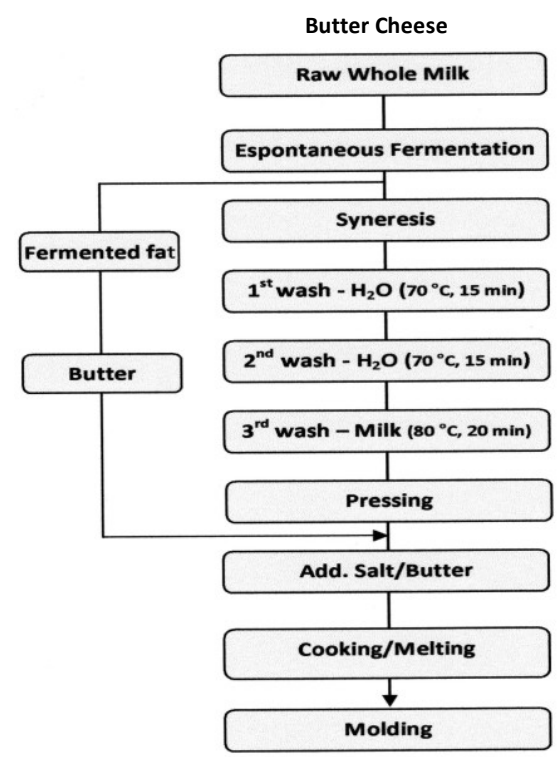

Figure 1 - Production flow chart of artisanal Marajó Butter cheese type.

During cheese preparation, raw milk was homogenized without the addition of a starter culture, submitted to spontaneous fermentation and kept at room temperature $\left(30{ }^{\circ} \mathrm{C}\right)$ for twenty-four hours. The fermented cream on the surface was removed to produce butter. Afterwards, the curd mass went through a manual handling to induce syneresis, and the whey was extracted. Then it was washed twice with water at a room temperature of about $30^{\circ} \mathrm{C}\left(2 \mathrm{~L}\right.$ of water $\mathrm{kg}^{-1}$ of curd mass) under heating $\left(70{ }^{\circ} \mathrm{C}, 15 \mathrm{~min}\right)$, for acidity reduction. A third wash with buffalo milk ( $2 \mathrm{~L}$ of milk kg${ }^{-1}$ of curd mass) was performed, also under heating (70 ${ }^{\circ} \mathrm{C}, 15 \mathrm{~min}$ ), to reincorporate flavor and components washed out by the water, that is, some soluble solids.

Posteriorly, to remove excess liquids, the mass was manually pressed. Salt ( $15 \mathrm{~g} \mathrm{~kg}^{-1}$ of curd mass) and butter (100 g of butter $\mathrm{kg}^{-1}$ of curd mass) from baking the fermented fat were added and submitted to heat treatment $\left(80^{\circ} \mathrm{C}, 20 \mathrm{~min}\right)$. In this stage the curd stretching occurs, which is performed by manual beating. The melted mass was distributed in polypropylene plastic packages (PP) and cooled to room temperature $\left(30^{\circ} \mathrm{C}\right)$. All cheeses were refrigerated $\left(7^{\circ} \mathrm{C}-8^{\circ} \mathrm{C}\right)$ until the analyses were carried out. A package of each formulation was used for this purpose.

\subsection{Physicochemical analysis}

The cheese fat was determined by the Mojonnier's method [11]. The total protein content was estimated by the micro-Kjeldal's method; moisture was determined by kiln drying at $105^{\circ} \mathrm{C}$ until constant weight; and the fixed mineral residue was assessed by calcination in muffle furnace [11]. The factor used in conversion from nitrogen to total protein was 6.38 . The cheese $\mathrm{pH}$ was determined by the potentiometric method (Metrohn Pensalab Instrumentação Analítica Ltda., São Paulo, SP, Brazil) and the acidity was estimated by the determination of the percentage of lactic acid [11]. Determination of fat content in dry matter was made indirectly, by calculating the ratio between the fat content and the total solid content of the cheese [12]. The analyses of physicochemical composition were evaluated seven days after the production of the formulations. Analyses were performed in duplicates.

\subsection{Texture Profile Analysis (TPA)}


The textural characteristics were evaluated two days after the production of the formulations, using a device from Stable Micro Systems, model TA.XT Plus (Surrey, England), equipped with a cell charge of $25 \mathrm{~kg}$.

Cylindrical samples, with diameters and heights equal to $20 \mathrm{~mm}$, were removed from random points in the cheese, in order to get uniform and homogeneous samples, and kept at room temperature $\left(21{ }^{\circ} \mathrm{C}\right)$. The texture profile was obtained by a double compression test of the cheese cylinder, at room temperature, using a cylindrical compression probe with a $75 \mathrm{~mm}$ diameter (P75). Compression was performed at a constant speed of $2.0 \mathrm{~mm} \mathrm{~s}^{-1}$ with contact strength equal to $5 \mathrm{~g}$ until the sample height was reduced to $10 \mathrm{~mm}$ (that means $50 \%$ of the initial height). Data was obtained by software Texture Expert 1.20 for Windows (Stable Micro System). Five independent replicates were produced.

\subsection{Color Measurement}

Two days after the production of the formulations, the cheese color parameters were evaluated using a colorimeter Hunter Lab, model Color Quest XE (Reston, EUA), according to definitions proposed by the Commission Internationale de l'Éclairage. The value $\mathrm{L}^{*}$ represents luminosity and indicates how bright or dark the product is; it refers to the object's capacity to reflect or transmit light and varies from zero (totally black) to one hundred (totally white), the higher the value of $\mathrm{L}^{*}$ is, the brighter the object is. The chromaticity coordinate $\mathrm{a}^{*}$ is an indicator of green (-) and red (+), while $\mathrm{b}^{*}$ is an indicator of blue $(-)$ and yellow $(+)$. The values $\mathrm{a}^{*}$ and $\mathrm{b}^{*}$ were used to calculate Hue $\left(\mathrm{h}^{\circ}\right)$, tone angle or color, and Chroma $\left(\mathrm{C}^{*}\right)$, color intensity (chromaticity of color saturation), using the following formulas: $h=\tan ^{-1}\left(b^{*} / a^{*}\right)$ and $C^{*}=\left(a^{* 2}+b^{* 2}\right)^{1 / 2}$. The determinations were performed in triplicate, with the calibrated equipment, using 10 samples, 5 from the center and 5 from the periphery of the cheeses from each formulation [10].

\subsection{Statistical analysis}

In order to compare the physicochemical properties, the averages of experimental data were submitted to analysis of variance (One Way-ANOVA). When significant differences were observed $(\mathrm{P} \leq 0.05)$, Tukey's test was applied. The correlation between texture and physicochemical parameters was expressed as Pearson's correlation coefficient. All analyses used a significance level of 5\% ( $\mathrm{P} \leq 005)$. Values of $\mathrm{P}$ were obtained with software BioEstat 5.0.

\subsection{Physicochemical Composition}

\section{Results and Discussion}

Table 1 displays the results of the compositions of each cheese formulation. Statistical differences were found for values of $\mathrm{pH}$, moisture, minerals, protein and fat; however, acidity in the four formulations did not present significant. As expected, cheese made with $100 \%$ of buffalo milk $\left(\mathrm{B}_{100}\right)$ had the higher values of protein, fat and minerals and the lower values of $\mathrm{pH}$ and moisture [13].

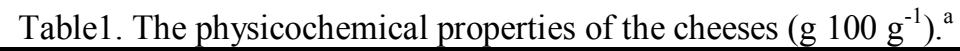

\begin{tabular}{lccccccc}
\hline \multirow{2}{*}{ Formulation } & \multicolumn{5}{c}{ Physicochemical Parameters } \\
\cline { 2 - 7 } & $\mathrm{pH}$ & Moisture (\%) & Ashes (\%) & Fat (\%) & Protein (\%) & FDM $^{\mathrm{b}}(\%)$ & Acidity $^{\mathrm{c}}(\%)$ \\
\hline $\mathrm{B}_{100}$ & $5.51 \pm 0.01^{\mathrm{d}}$ & $47.38 \pm 0.06^{\mathrm{d}}$ & $2.48 \pm 0.01^{\mathrm{d}}$ & $37.00 \pm 0.01^{\mathrm{d}}$ & $26.40 \pm 0.14^{\mathrm{d}}$ & $75.04 \pm 0.10^{\mathrm{d}}$ & $0.18 \pm 0.01$ \\
$\mathrm{~B}_{80}$ & $5.60 \pm 0.01^{\mathrm{e}}$ & $49.93 \pm 0.13^{\mathrm{e}}$ & $2.37 \pm 0.01^{\mathrm{e}}$ & $31.00 \pm 0.01^{\mathrm{e}}$ & $25.05 \pm 0.21^{\mathrm{e}}$ & $59.54 \pm 0.15^{\mathrm{e}}$ & $0.16 \pm 0.01$ \\
$\mathrm{~B}_{70}$ & $5.97 \pm 0.01^{\mathrm{f}}$ & $50.25 \pm 0.14^{\mathrm{f}}$ & $2.19 \pm 0.01^{\mathrm{f}}$ & $29.00 \pm 0.01^{\mathrm{f}}$ & $24.90 \pm 0.01^{\mathrm{e}}$ & $57.29 \pm 0.16^{\mathrm{f}}$ & $0.16 \pm 0.01$ \\
$\mathrm{~B}_{60}$ & $5.59 \pm 0.01^{\mathrm{e}}$ & $50.70 \pm 0.12^{\mathrm{f}}$ & $2.17 \pm 0.01^{\mathrm{f}}$ & $27.60 \pm 0.01^{\mathrm{g}}$ & $24.80 \pm 0.01^{\mathrm{e}}$ & $57.29 \pm 0.14^{\mathrm{f}}$ & $0.18 \pm 0.01$ \\
P value & 0.0004 & 0.0007 & 0.0004 & 0.0001 & 0.0019 & 0.0002 & 0.5518 \\
\hline
\end{tabular}

${ }^{\mathrm{a}}$ Each value represents mean \pm standard deviation; data represent means of two replicates $(n=6)$.

${ }^{\mathrm{b}} \mathrm{FDM}-$ Fat in dry matter.

${ }^{\mathrm{c}}$ Lactic acid.

${ }^{\mathrm{d}-\mathrm{g}}$ Means with different superscript letters within the same column are significantly different $(\mathrm{P}<0.05)$.

The lower moisture in $\mathrm{B}_{100}$ formulation may be explained by the higher amount of fat present in buffalo milk. This result is according to reports by Souza et al., 2012 [14] that also reported in their studies an increase in the moisture as the fat rate was reduced. In other formulations, the decrease of protein, fat and mineral amounts was due to the lower amounts of those components in cow milk, which was added in larger proportions.

According to Brazilian legislation, "cottage" cheese must have a maximum moisture content of $65 \%$ and a minimum fat content on a dry weight basis of 55\% [15]. Analysis of moisture and fat concentrations in the four formulations shows that those products may be classified as Butter Cottage Cheese, a melted cheese also called processed cheese, typically from the northern region of Brazil. 
The partial substitution of $20 \%, 30 \%$ and $40 \%$ of buffalo milk for cow milk caused the reduction of fat in $16.2 \%, 21.6 \%$ and $25.4 \%$, and protein in $5.2 \%, 5.7 \%$, and $6 \%$, respectively. Thus, Butter cheeses manufactured with the partial addition of cow milk have more moisture and lower concentration of protein, minerals and calories.

\subsection{Texture Profile Analysis (TPA)}

Results for Texture Profile Analysis (TPA) are compiled in Table 2.

When there is a reduction of fat, the microstructure of the protein net is changed; normally hardness and elasticity increase, while adhesiveness and cohesiveness decrease [16]. On the other hand, cheeses with high amounts of fat are characterized by attributes such as more softness, cohesiveness and good flavor.

Table 2. Textural characteristics of the cheeses ${ }^{\mathrm{a}}$.

\begin{tabular}{lccccccc}
\hline \multirow{2}{*}{$\begin{array}{c}\text { Formulatio } \\
n\end{array}$} & $\begin{array}{c}\text { Hardness } \\
(\mathrm{N})\end{array}$ & \begin{tabular}{c} 
Fracturabilit \\
\cline { 2 - 8 }
\end{tabular} & $\begin{array}{c}\mathrm{y} \\
(\mathrm{N})\end{array}$ & Adhesiveness & $\begin{array}{c}\text { Springiness } \\
(\mathrm{mm})\end{array}$ & $\begin{array}{c}\text { Cohesiveness } \\
\text { Gumminess }\end{array}$ & $\begin{array}{c}\text { Ghewiness } \\
(\mathrm{N})\end{array}$ \\
\hline $\mathrm{B}_{100}$ & $28.20 \pm 4.32$ & $30.80 \pm 2.94$ & $-2.257 \pm 0.549$ & $7.24 \pm 0.40^{\mathrm{b}}$ & $0.66 \pm 0.05^{\mathrm{b}}$ & $19.93 \pm 3.07^{\mathrm{b}}$ & $143.97 \pm 23.27^{\mathrm{b}}$ \\
$\mathrm{B}_{80}$ & $27.23 \pm 4.98$ & $28.83 \pm 3.86$ & $-2.329 \pm 1.567-$ & $5.87 \pm 0.66^{\mathrm{c}}$ & $0.51 \pm 0.02^{\mathrm{c}}$ & $11.73 \pm 1.33^{\mathrm{c}}$ & $69.28 \pm 10.57^{\mathrm{c}}$ \\
$\mathrm{B}_{70}$ & $26.87 \pm 3.27$ & $28.60 \pm 4.56$ & $-1.951 \pm 1.066$ & $5.47 \pm 0.49^{\mathrm{c}}$ & $0.45 \pm 0.04^{\mathrm{c}}$ & $11.30 \pm 2.66^{\mathrm{c}}$ & $62.50 \pm 16.44^{\mathrm{c}}$ \\
$\mathrm{B}_{60}$ & $26.10 \pm 2.53$ & $27.83 \pm 3.97$ & $-1.662 \pm 0.300$ & $5.37 \pm 0.98^{\mathrm{c}}$ & $0.45 \pm 0.05^{\mathrm{c}}$ & $10.08 \pm 2.08^{\mathrm{c}}$ & $54.80 \pm 16.51^{\mathrm{c}}$ \\
$\mathrm{P}$ value & 0.596 & 0,075 & 0.7178 & $<0.0001$ & $<0.0001$ & $<0,0001$ & $<0.0001$ \\
\hline
\end{tabular}

${ }^{\mathrm{a}}$ Each value represents mean \pm standard deviation; data represent means of five replicates $(n=15)$.

${ }^{\mathrm{b}-\mathrm{c}}$ Means with different superscript letters within the same column are significantly different $(\mathrm{P}<0.05)$.

However, in this study, the reduction of fat, caused by the increase of cow milk concentration, reduced the values of elasticity cohesiveness, gumminess and chewiness while not significantly changing the values of hardness, brittleness and adhesiveness.

Hardness, the measure of the strength needed to compress a sample producing a deformation, is explained by resistance of the protein matrix of cheese; in other words, lower concentrations of protein reduced the hardness. However, the joint action of protein and fat reduction, caused by the cow milk, kept the cheese's hardness. In this case, lower values of hardness, produced by the lower concentration of proteins, possibly were balanced by the lower amount of fat that caused higher resistance to deformation, an antagonistic effect [17].

Values of hardness were lower when compared with other types of cheese, for example, Cheddar, Gouda, Mozzarella and rennet cheese; they were respectively 47 N, 77 N, 68 N and 36 N [18]. On the other hand, the values of hardness were higher than the ones found in fresh cheese [19].

Elasticity, or recovery after compression, as seen in Table 2, went from $7.24 \mathrm{~mm}$ to $5.37 \mathrm{~mm}$, showing that the increase of cow milk concentration reduced the elasticity of Butter Cheese, with formulation $\mathrm{B}_{100}$ significantly differed from others which had similar elasticity. In cheese, the protein matrix produces elasticity [8] and is the main factor responsible for flexibility and recovery after tension removal. Thus, as there was a decrease in the amount of protein with the increase of cow milk concentration, TPA values for elasticity decreased. In comparison to Cheddar, Gouda, and Mozzarella, that have elasticity values from 8.5 to $10.0 \mathrm{~mm}$, Butter Cheese does not recover well after compression [20].

Finally, for the parameters cohesiveness and chewiness the values decreased with the decline in the concentration of added cow milk. The cohesion was between 0.45 and 0.66 , contrasting with $0.21,0.28$ and 0.41 for cheeses like fresh Cheddar, Gouda and Mozzarella [20]. Therefore, artisanal Marajó Butter cheese is quite cohesive. The values for chewiness were higher to those reported for cheese of the Feta type, elaborated from buffalo milk [21].

Thus, Butter cheeses manufactured with the partial addition of cow milk kept the same hardness, fracturability and adhesiveness, but lower elasticity, cohesiveness and chewiness.

\subsection{Correlation between physicochemical and texture parameters}

Pearson's correlation coefficients between texture parameters and physicochemical characteristics are presented in Table 3. Analyzing the values found, it was observed that moisture had significant and strongly negative correlation with elasticity, cohesiveness, gumminess and chewiness. On the other hand, fat and protein had significant and strongly positive correlations with elasticity, cohesiveness, gumminess and chewiness. The $\mathrm{pH}$ did not significantly influence alterations of texture parameters. The meaning and importance of correlation coefficients may be related to the type of formulation and, in this experimental model, the increase of cow milk concentration caused the decrease of protein and fat concentration, and also, the increase of moisture, which played an important role on the decrease of elasticity, cohesiveness, gumminess and chewiness of cheeses. 
Table 3. Linear correlation between physicochemical and texture parameters. ${ }^{\mathrm{a}}$

\begin{tabular}{|c|c|c|c|c|c|c|c|}
\hline \multirow{2}{*}{ Formulation } & \multicolumn{7}{|c|}{ Texture Characteristics } \\
\hline & Hardness & Fracturability & Adhesiveness & Springiness & Cohesiveness & Gumminess & Chewiness \\
\hline Moisture & $-0.705^{\mathrm{NS}}$ & $-0.843^{\mathrm{NS}}$ & $0.627^{\mathrm{NS}}$ & $-0.997^{\mathrm{S}}$ & $-0.983^{\mathrm{S}}$ & $-0.986^{\mathrm{S}}$ & $-0.992^{\mathrm{S}}$ \\
\hline $\mathrm{FDM}^{\mathrm{b}}$ & $0.674^{\mathrm{NS}}$ & $0.765^{\mathrm{NS}}$ & $-0.548^{\mathrm{NS}}$ & $0.996^{\mathrm{S}}$ & $0.983^{\mathrm{S}}$ & $0.986^{\mathrm{S}}$ & $0.967^{\mathrm{S}}$ \\
\hline Protein & $0.675^{\mathrm{NS}}$ & $0.796^{\mathrm{NS}}$ & $-0.569^{\mathrm{NS}}$ & $0.998^{\mathrm{S}}$ & $0.982^{\mathrm{S}}$ & $0.985^{\mathrm{S}}$ & $0.999^{\mathrm{S}}$ \\
\hline $\mathrm{pH}$ & $-0.632^{\mathrm{NS}}$ & $-0.065^{\mathrm{NS}}$ & $0.272^{\mathrm{NS}}$ & $-0.541^{\mathrm{NS}}$ & $-0.612^{\mathrm{NS}}$ & $-0.607^{\mathrm{NS}}$ & $-0.571^{\mathrm{NS}}$ \\
\hline
\end{tabular}

${ }^{a}$ Results expressed as Pearson's correlation coefficient (r).

${ }^{\mathrm{b}}$ Fat in dry matter.

$\mathrm{S}$ - Significant $(\mathrm{P}<0.05)$.

NS - Not significant $(\mathrm{P} \geq 0.05)$.

\subsection{Color Analysis}

Table 4 shows the average values of color parameters of cheeses obtained by instrumental measures. For the four formulations, parameter $\mathrm{a}^{*}$ had negative values, appearing slightly green in color, while parameter $b^{*}$ had positive values, appearing slightly yellow in color. For variables $L^{*}, a^{*}, b^{*}$ and $h^{0}$ significant differences were found $(\mathrm{P}<0.05)$ between the four formulations.

Table 4. Mean composition and Hunter color $\left(\mathrm{L}^{*}, \mathrm{a}^{*}, \mathrm{~b}^{*}, \mathrm{C}^{*}, \mathrm{~h}^{\circ}\right)$ values of cheeses"a

\begin{tabular}{lccccc}
\hline \multirow{2}{*}{ Formulation } & \multicolumn{5}{c}{ Hunter Color } \\
\cline { 2 - 5 } & $\mathrm{L}^{*}$ & $\mathrm{a}^{*}$ & $\mathrm{~b}^{*}$ & $\mathrm{C}^{*}$ & $\mathrm{~h}^{\mathrm{o}}$ \\
\hline $\mathrm{B}_{100}$ & $88.67 \pm 4.90^{\mathrm{b}}$ & $-5.41 \pm 0.48^{\mathrm{b}}$ & $17.47 \pm 1.04^{\mathrm{b}}$ & $19.53 \pm 0.89$ & $106.07 \pm 1.86^{\mathrm{b}}$ \\
$\mathrm{B}_{80}$ & $86.71 \pm 3.20^{\mathrm{b}}$ & $-4.41 \pm 0.42^{\mathrm{c}}$ & $18.29 \pm 1.06^{\mathrm{c}}$ & $18.02 \pm 0.85$ & $103.14 \pm 0.48^{\mathrm{c}}$ \\
$\mathrm{B}_{70}$ & $86.56 \pm 5.52^{\mathrm{b}}$ & $-3.67 \pm 0.68^{\mathrm{d}}$ & $18.85 \pm 1.75^{\mathrm{c}, \mathrm{d}}$ & $18.86 \pm 2.05$ & $100.70 \pm 2.46^{\mathrm{d}}$ \\
$\mathrm{B}_{60}$ & $84.85 \pm 4.96^{\mathrm{c}}$ & $-3.53 \pm 0.56^{\mathrm{e}}$ & $21.38 \pm 1.54^{\mathrm{e}}$ & $21.68 \pm 1.15$ & $99.41 \pm 1.63^{\mathrm{e}}$ \\
$\mathrm{P}$ value & 0.0228 & $<0.0001$ & $<0.0001$ & 0.8660 & $<0.0001$ \\
\hline
\end{tabular}

${ }^{\mathrm{a}}$ Each value represents mean \pm standard deviation; data represent means of five replicates $(n=30)$.

${ }^{b-e}$ Means with different superscript letters within the same column are significantly different $(\mathrm{P}<0.05)$.

As expected, cheese produced with $100 \%$ of buffalo milk had a higher value for luminosity (white component), differing only in $\mathrm{B}_{60}$. In the same way, formulation $\mathrm{B}_{100}$ reached higher values of the chromaticity component of green color, caused by the presence of the blue-green pigment (biliverdin), which is present in buffalo milk and absent in cow milk [3]. However, the presence of $\beta$-carotene pigment in cow milk caused an increase in the yellow chromaticity component in formulations produced with this type of milk [3].

Values of $\mathrm{C}^{*}$ that quantify saturation or color intensity, were not significantly affected by the addition of cow milk. However, the tone angle $\left(\mathrm{h}^{\circ}\right)$, indicated the existence of significant variations in formulation tonalities. In this case, the increase in cow milk concentration did not cause an increase in color intensity but did cause a change in the yellow-greenish tonality, with an emphasis in yellow tones.

\section{Conclusion}

Partial addition of cow milk improved some properties of artisanal Marajó Butter cheese. Moisture and $\mathrm{pH}$ shown a significantly increased, however, smaller amounts of protein, minerals and fat were found. Similarly, the instrumental elasticity, cohesiveness and chewiness decreased. The increase of moisture played an important role on the decrease of elasticity, cohesiveness, gumminess and chewiness of these cheeses. The increase in cow milk concentration did not cause an increase in color intensity but changed the yellow-greenish tonality, with an emphasis in yellow tones.

\section{Acknowledgements}

The authors gratefully thank the Coordenação de Aperfeiçoamento de Pessoal de Nível Superior (Capes) for their financial support and Secretaria de Estado da Agricultura e Desenvolvimento Rural - Soure/PA (SAGRI) and cheese producers in the city Cachoeira do Arari, for technical help with the cheese processing.

\section{References}

[1] A. Figueiras and M. Quadros, Queijo Marajó: Começa a fase industrial, Revista Agroamazônia, (3), 2002, 36-37.

[2] Pará, Agência Estadual de Defesa Agropecuária do Estado do Pará. Portaria nº 418 de 04 de março de 2013 aprova o Regulamento Técnico para a Produção do Queijo do Marajó. Diário Oficial do Estado do Pará, 2013 marc. 06

[3] M. H. Abd El-Salam and S. A. El-Shibiny, A comprehensive review on the composition and properties of buffalo milk, Dairy Science \& Technology, 91(6), 2011, 663- 690. 
[4] E. Medhammar, R. W. Bettoni, B. Stadlmayr, E. Nilsson, U. R Charrondine and B. Burlingame, Composition of milk from minor dairy animals and buffalo breeds: a biodiversity perspective, Journal of Science Agriculture, 92(3), 2012, 445 - 474.

[5] Usda. National Nutrient Database for Standard Reference, 2009, http://www.nal.usda. gov/fnic/foodcomp/search, accessed oct. 02, 2012.

[6] J. H. Prentice, K. R. Langley and R. J. Marshall, Cheese Rheology, in: Cheese: Chemistry, Physics and Microbiology (Fox PF et al., editor: Chapman and Hall, 1993).

[7] F. R. Jack, A. Paterson and J. R. Piggot, Relationships between rheology and composition of Cheddar cheeses and texture as perceived by consumers, International Journal of Food Science \& Technology, 28, 1993, 293-302.

[8] P. F. Fox, T. P. Guinee, T. M Cogan and P. L. H. Mc Sweeney, Cheese rheology and texture, in: Fundamentals of cheese science (Fox P.F. et al., editor: Aspen Publisher Inc, 2000).

[9] A. H. Chen, J. W. Larkin, C. J. Clark and W. E. Irwin, Textural analysis of cheese, Journal of Dairy Science, 62, $1979,901-907$.

[10] B. P. Pathare, U. L. Opara, F. A. J. Al-Said, Colour Measurement and Analysis in Fresh and Processed Foods: A Review, Food Bioprocess Technology (on line), http://link.springer.com/article/10.1007\%2Fs11947-012-0867-9\#page-1, accessed oct. 28 , 2012.

[11] Brasil. Ministério da Agricultura, Pecuária e Abastecimento. Secretaria de Defesa Agropecuária - Instrução Normativa no. 68, de 12 de dezembro de 2006. Métodos Analíticos Físico-Químicos, para Controle de Leite e Produtos Lácteos. Diário Oficial da União, Brasília-DF, 2006 dez. 14.

[12] D. B. C. Pereira, P. H. F. Silva, L. L. Oliveira and J. L. C. G. C Costa, Físico-química do leite e derivados-Métodos analíticos (Juiz de Fora-MG: Oficina de Impressão Gráfica e Editora Ltda., 2001).

[13] A. G. Karahan, A. Kart, A. Akoğlu and M. L. Çakmakç, Physicochemical properties of low-fat soft cheese Turkish Beyaz made with bacterial cellulose as fat mimetic, International Journal of Dairy Technology, 64(4), 2011, 502-508.

[14] V. R. Souza, J. D. S Carneiro, S. M. Pinto, A. B. Souza and R. Stephani, Efeito da concentração de gordura nas propriedades físicas, químicas e sensoriais do queijo petit suisse elaborado com retenção de soro, Revista do Instituto de Laticínios Cândido Tostes, 67(386), 2012, $20-28$.

[15] Mercosul. Regulamento Mercosur/Gmc. Resolução no 82, de 11 de outubro de1996. Estabelece o Regulamento Técnico Mercosul de Identidade e Qualidade do Requeijão. Tratado de Assunção, Protocolo de Ouro Preto, artigo 10 da Decisão n 4/91 do Conselho do Mercado Comum. Diário Oficial da República Federativa do Brasil, 1996 oct. 11.

[16] A. H. Chen, Larkin JW, Clark CJ, Irwin WE, Textural analysis of cheese, Journal of Dairy Science, 62, 1979, 901-907.

[17] C. C. Lobato, C. E. J. Vernon, L. I. Guerrero, S. J. Soriano and B. H. Escalona, Use of fat blends in cheese analogs: Influence on sensory and instrumental textural characteristics. Journal Texture Study, 28, 1998, 619-632.

[18] M. H. Tunick and D. L. Van Hekken, Torsion gelometry of cheese. Journal of Dairy Science, 85, 2002, $2743-2749$.

[19] M. H. Tunick and D. L. Van Hekken, L. Guo and P. M. Tomasula, Chemistry of Queso Fresco. In: Hispanic Foods: Chemistry and Bioactive Compounds; American Chemical Society Symposium Series, Washington, DC: American Chemical Society Publication; 2012. p. 11-23.

[20] M. H. Tunick and D. L. Van Hekken, Torsion gelometry of cheese. Journal of Dairy Science, 85, 2002, 2743-2749.

[21] S. Kumar, S. K. Kanawjia, S. Kumar and S. Khatkar, Effect of rate of addition of starter culture on textural characteristics of buffalo milk Feta type cheese during ripening. Journal of Food Science and Technology (on line), 2011, 1-5. 